\title{
MASALAH-MASALAH HUKUM AKTUAL DALAM WACANA REFORMASI AGRARIA DI INDONESIA
}

\author{
Suparjo Sujadi ${ }^{1}$
}

Abstrak

This article does endeavor to launch many issues in recent agrarian reform in Indonesia. Many factors become considerations to conduct newly agrarian reforms and momentously. The prior agrarian reforms outstanding in the ideal agrarian and land tenure structure that has reflected many land conflicts needs adequate resolution. That situation coincides to the huge number of deprived people who living in less in public service such as food, education, health, living hood that have reflected any social-economic gaps. All of them ideally are the mostly agrarian concern to be accomplished by mainly idea to create ideal land tenure and access to land itself. Ultimately, the unfinished on delegation of power between central to local government in post decentralization law since 1999 has been substantial problems.

Kata kunci: hukum tanah, masalah-masalah aktual, reformasi agraria, indonesia

\section{Uraian tentang Reformasi Agraria di Indonesia}

Dalam sejarah program reformasi agraria di Indonesia yang dimulai dengan berlakunya UUPA memiliki visi dan misi ideal untuk dapat meningkatkan kemakmuran sosial-ekonomi rakyat Indonesia. Program landreform sebagai ujung tombak terdepan dalam pelaksanaan reformasi agraria menitikberatkan pengaturan yang mengubah ketimpangan struktur pemilikkan dan penguasaan tanah di Indonesia.

Hingga pasca reformasi 1998, ternyata permasalahan reformasi agraria masih juga belum memiliki perubahan yang signifikan dalam mencapai tujuan program landreform yang dicanangkan sejak 1960. Hal itu dapat dilihat pada berbagai kasus sengketa tanah di berbagai tempat seperti kasus pembebeasan tanah oleh pemerintah (kasus Kedungombo, kasus tanah adat Hebe-Ohee); ataupun kasus pendudukan tanah-tanah perkebunan yang marak belakangan ini oleh pihak-pihak yang mengklaim sebagai pemilik tanah dimaksud.

${ }^{1}$ Pengajar pada Kelompok Hukum Agraria dan Mata Kuliah Penatagunaan Tanah dan Landreform Program Sarjana FHUI, Jakarta sejak 1994. 
Masalah besar lainnya adalah berkenaan dengan masalah ketahanan pangan dan perumahan. Masalah pangan memiliki relevansi erat dengan sektor pertanian yang memerlukan alokasi sumber daya tanah-tanah pertanian yang semakin menurun luasnya. Penurunan luas tanah pertanian tersebut disebabkan adanya peningkatan kebutuhan tanah untuk berbagai keperluan seperti perumahan, kawasan industri, pusat pertokoan, infrastruktur.

Ada kesadaran melakukan reformasi agraria hal mana pada masa reformasi telah ada TAP MPR-RI NO. IX/TAP/MPR/2001 tentang "Pembaruan Agraria dan Pengelolaan Sumber Daya Alam". Namun dalam pandangan Said Nisar ketetapan tersebut masih mengandung banyak kelemahan dan sifatnya sangat kontoversial, dangat kompleks dan membingungkan. Persoalan agraria adalah persoalan yang compleks, antara lain ${ }^{2}$ :

a. Memahami dan menjaga "Political Equilibrium" dengan melakukan Reajusment dibidang Agraria;

Issue "land Reform" telah melanda hampir seluruh negara sedang berkembang. Pada masa pemerintahan President Macapagal di Philipina, President Betancourt di Venezuela dan pada masa pemerintahan Perdana Menteri Nehru di India telah menggunakan konsep "land reform" untuk menjawab ketidakstabilan dalam Negeri. Namun land reform ini tidak dapat meyelesaikan masalah. Muatan kebijakan pembaruan Agraria lebih banyak muatan politiknya dari pada mengejar misi yang sebenarnya. pelaksanaan land reform di lapangan akan menimbulkan banyak persoalan sosial sebelum tanah ini dibagi-bagikan kepada petani miskin. Terhadap tanah-tanah yang telah dimiliki oleh Petani itu harus dibarengi dengan kebutuhan alat-alat pembangunan lainnya.

Lapangan hidup disektor pertanian belum mampu menjadi tumpuan hidup para petani. Hal ini disebabkan bukan karena Undang-Undang Pokok Agraria tidak mendukung, tetapi adanya perangkap pada fenomena tenaga petani yang harus dibayar cash. Akibatnya banyak petani meninggalkan lahan pertanian lalu mereka masuk ke kota-kota besar menjadi buruh harian atau

${ }^{2}$ H. M. Said Nisar, "Kajian tentang Pembaruan Agraria dan Pengelolaan SDA TAP MPR NO: IX/MPR/2001", paper lepas. 
menarik becak. Kenapa hal seperti ini terjadi karena Pemerintah belum berhasil mengubah wajah lapangan kerja di bidang pertanian menjadi "Industrialized Farming, atau Commercial Farming". Dalam ungkapan yang sistematis adalah belum adanya link and match dalam pelaksanaan program landreform.

"Strategy" Pertanian ini adalah strategi politik. Dalam suasana perang ekonomi (Economic War) pertanian ini selalu menjadi sasaran untuk diobrak-abrik sehingga pola ketergantungan negara berkembang kepada negara industri maju menjadi lebih langgeng dan bahkan bersifat permanent.

b. Prinsip yang terdapat dalam Pasal 4 dari TAP MPR Nomor IX/MPR/2001 dimulai dari point a sampai dengan point II (semuanya ada 11 point) pada dasarnya hanya merupakan pengulangan yang terdapat dalam Undang-Undang Dasar 45, Undang-Undang Pokok Agraria GBHN, dan Undang-Undang RI Nomor 39 tahun 1999 tetnag Hak Asasi Manusia dan juga beberapa aturan tertulis lainnya.

Point a dari Pasal 4 dimaksud berbunyi sebagai berikut: Pembaruan Agraria dan Pengelolaan Sumber Daya Alam harus dilaksanakan sesuai dengan prinsip-prinsip:

a. Memelihara dan mempertahankan keutuhan Negara Kesatuan Republik Indonesia. Kalimat "Negara Kesatuan Republik Indonesia" sebagai suatu prinsip sudah banyak kali diulang-ulang dalam teks UndangUndang Dasar 45 dengan berbagai penampilan kata-kata seperti: PERSATUAN INDONESIA, NEGARA KESATUAN REPUBLIK INDONESIA dstnya.

b. Memelihara dan menjunjung tinggi hak asasi manusia Indonesia. Kalimat seperti ini juga adalah fotocopy verbatim dari Undang-Undang 39 tahun 1999.

c. Prinsip yang lainnya yaitu prinsip transparansi, prinsip keadilan, prinsip kelestarian lingkungan, prinsip keterpaduan pembangunan, prinsip pengakuan hak masyarakat adat, prinsip keseimbangan, dan prinsip decentralisasi.

Semua prinsip yang termuat dalam Pasal 4 diatas tidak ada yang bersifat baru dan spesial. Oleh karena prinsip-prinsip ini sudah umum sifatnya dan ditemukan disemua perundang-undangan yang ada, maka keberadaannya sangat tidak diperlukan. 
c. TAP ini memuat dua arah kebijakan yaitu: Pembaruan Agraria dan Pengelolaan Sumber Daya Alam. Kelemahan TAP ini yang sekaligus merupakan sumber kebingungan adalah:

1) Kajian terhadap UUPA 1960 sudah berulangkali dilakukan bahkan sejak tahun 1966 berbagai Undang-Undang terkait dengan Agraria sudah diundangkan misalnya: UU Kehutanan No. 5 (1967); UU Pokok Pertambangan No. 11 1967, UU No. 8 tahun 1971 tentang Pertambangan Minyak GAS dan BUMI, dan sebagainya.

Perdebatan di bidang agraria sudah berlangsung selama dua abad akan selalu meliputi isu-isu berikut ini :

a. Bagaimana meningkatkan produksi pangan (Agrarian Production);

b. Bagaimana mensejahteraan masyarakat Pedesaan;

c. Bagaimana menciptakan "Keadilan sosial" ditengahtengah masyarakat.

Ketiga isu tersebut pada hakekatnya menyangkut kinerja institusi Pemerintahan dari Pusat hingga ke daerah dan bukan terletak pada usaha untuk melakukan pengkajian ulang berbagai peraturan dibidang agraria lalu dicarikan dasar hukumnya melalui suatu TAP.

Sebagai contoh dapat kita ambil paradigma institusi "Walikota" diseluruh Indonesia yang tidak pernah berubah dari dulu hingga hari ini. Kesibukannya hanya berfokus pada soal-soal administrasi, soal personil, dan mengejar pajak Bumi dan Bangunan. Keberhasilan seorang Walikota dan daparat dibawahnya ditentukan pada target pajak yang diperolehnya.

Bahkan pernah ada kejadian di Sulawesi Selatan seorang petani tidak mampu membayar Pajak Bumi dan Bangunan pada waktunya lalu piring dan barang-barang berharga yang ada di dalam rumah sang petani disita (oleh petugas pajak). Kejadian seperti ini banyak ditemukan dilapangan. Alasannya adalah bukan karena Undang-Undang Pokok Agraria dan sejenisnya yang sudah tidak bisa menjawab tantangan pembangunan.

Pembagunan agraria tidak saja terletak kepada hukum yang ada tetapi bagaimana programnya dibuat dan pelaksanaannya. Ada banyak peristiwa dimana Walikota dan 
aparat dibawahnya hanya tinggal diam, tidak mengambil tindakan umpamanya dalam hal:

a) Bagaimana tindakan Pemerintah dalam peristiwa banjir yang melanda daerah pertanian dan tambak setiap tahun;

b) Bagaimana cara mempermudah petani tambak memperoleh bibit dan pupuk;

c) Bagaimana cara mengatasi hama tanaman termasuk penyakit yang melanda pertanian dan perikanan setiap tahun;

Persoalan-persoalan diatas dihadapi oleh petani sendiri dan pemerintah hanya tinggal diam saja. Berita seperti ini hanya merupakan konsumsi pers saja. Aparat pemerintah tidak pernah merasa berdosa sehingga tidak merasa bertanggungjawab. Persoalannya sekali lagi bukan karena UUPA yang salah sehingga perlu dirobah, tetapi paradigma institusi dan bagaimana programnya di lapangan yang memerlukan pemikiran ulang ke arah yang lebih baik.

2) Potensi Sumber Daya Alam Indonesia yang kaya dan beragam.

Kondisi ini telah memperoleh atensi dari seorang peneliti Carolyn Mar dengan mengatakan: "Indonesia is fabulously rich and Indonesia is desperately poor" (Indonesia kaya secara menakjubkan dan miskin secara menyedihkan).

Persoalan yang ada pada Sumber Daya Alam berbeda dengan yang ada di bidang kepemilikan tanah (Undang-Undang Agraria). Ada beberapa fakta yang sering terungkap di lapangan:

a) Investor-investor asing yang mengelola Sumber Daya Alam seperti "Newmon" di Propensi NTB yang mengelola sumber daya mineral lebih banyak menguntungkan para Investor.

b) Pengrusakan lingkungan sudah merupakan bahagian tak terpisahkan dengan kegiatan Investor

c) Kasus kelaparan yang menyebabkan meninggalnya 250 penduduk di Yakuhimo, di Papua yang notabene memiliki sumber daya dan kekayaan alam yang melimpah seperti yang dieksploitasi Freeport yang secara nominal lebih dari cukup untuk membiayai 
pembangunan di seluruh Indonesia. Namun realitas kelaparan sebagai penyebab matinya 250 jiwa sungguh menegaskan pendapat Carolyn Mar tersebut.

Berkaitan dengan fenomena semakin terkonsentrasinya pemilikan dan penguasan tanah pada sekelompok kecil masyarakat dapat dilihat baik di perdesaan maupun perkotaan. Di perdesaan, konsentrasi penguasaan tanah dapat dilihat dari beberapa hasil sensus pertanian dalam beberapa dekade terakhir. Sensus pertanian tahun 1993 menunjukkan bahwa 69\% luas tanah pertanian dikuasai oleh $16 \%$ rumah tangga perdesaan, sementara $31 \%$ luas tanah pertanian sisanya dikuasai oleh sebagian besar petani kecil dan tunakisma (sebesar $84 \%$ rumah tangga perdesaan).

Pada sisi lain, dalam kurun waktu tiga dekade terakhir ini luas rata-rata penguasaan tanah per rumah tangga pertanian semakin mengecil yaitu 1,05 hektar pada tahun 1983 menjadi 0,74 hektar pada tahun 1993 dan diperkirakan menurun tajam pada sensus pertanian 2003 yang saat ini sedang berlangsung. Sementara angka rata-rata penguasaan tanah di Jawa saat ini diperkirakan hanya mencapai 0,2 hektar per rumah tangga pertanian. Luas rata-rata penguasaan tanah yang sangat kecil ini jelas tidak lagi mampu mencukupi kebutuhan rumah tangga pertanian tersebut. Fenomena tersebut semakin diperburuk dengan adanya fragmentasi tanah yang semakin tidak dapat dihindari, alih fungsi tanah pertanian ke penggunaan nonpertanian yang tidak terkendali, masalah kerusakan lingkungan sebagai akibat eskploitasi yang berlebihan, dan masalah lainnya.

Gambaran konsentrasi pemilikan dan penguasaan tanah di perkotaaan dapat dilihat dari semakin banyaknya kelompok miskin yang tersisih dan bahkan kehilangan tanahnya untuk berbagai kepentingan pembangunan. Hal ini terkait dengan tata ruang perkotaan yang kurang memberikan akses kelompok masyarakat miskin untuk turut menikmati adanya perubahan penggunaan tanah.

Di sisi lain, dalam waktu beberapa tahun terakhir ini khususnya pada masa krisis ekonomi, pendudukan atas tanah yang sudah memiliki status hak atas tanah "tertentu" terjadi baik di daerah perkotaan maupun perdesaan. Hal ini berdampak pada hilangnya kepercayaan investor untuk menanamkan modalnya di Indonesia sebagai akibat dari tidak memadainya jaminan kepastian hukum atas tanah, dan masalah lainnya.

Untuk itulah relevan dengan komentar Carolyn Mar di atas amat diperlukan pelaksanaan reformasi agraria di Indonesia secara terus-menerus, sistematis dan menyelesaikan masalah keserasian, keseimbangan dalam struktur pemilikkan, penguasaan dan penggunaan tanah banyak hal yang mesti dipikirkan jalan keluar terbaik untuk melaksanakan program reforma agraria tersebut. 


\section{Masalah-Masalah Pertanahan yang Aktual dan di Masa Depan}

Adapun dalam kerangka tantangan jaman dan waktu hingga sampai pada perkembangan terakhir di Indonesia, masih amat diperlukan reformasi agraria dengan mengingat masalah-masalah aktual yang secara khusus dikelompokkan dalam uraian berikut ini.

\section{A. Rencana pemerintah melakukan redistribusi tanah 8,5 juta ha (60\% untuk petani tuna kisma); dan sisanya $40 \%$ untuk perumahan dengan jangka waktu hak 100 tahun}

Pemerintah akan melaksanakan reformasi agraria secara bertahap mulai tahun 2007 hingga 2014. Tanah seluas 8,15 juta hektar akan dibagikan ke masyarakat miskin yang memenuhi kriteria tertentu dan pengusaha dengan ketentuan terbatas. Dalam Acara Simposium Agraria Nasional III di Jakarta, Selasa 12 Desember Kepala Badan Pertanahan Nasional Joyo Winoto mengatakan, pembagian tanah kepada masyarakat miskin akan mulai dilakukan sekitar akhir April 2007. Dalam tahap awal, 5.000 keluarga miskin akan diberikan tanah bersertifikat. Luas tanah yang dibagikan untuk setiap keluarga berbeda-beda bergantung pada kebutuhan dan ketersediaan lahan di setiap daerah.

Diperkirakan sebanyak 6 juta hektar lahan akan dibagikan bagi masyarakat miskin dan 2,15 juta hektar sisanya diberikan kepada pengusaha untuk usaha produktif dengan tetap melibatkan petani perkebunan. Negara dapat mencabut kembali pemberian tanah tersebut jika tidak dapat dimanfaatkan untuk usaha produktif.

Tanah yang akan dibagikan berasal dari lahan kritis, hutan produksi konversi, tanah telantar, tanah milik negara yang hak guna usahanya habis, maupun tanah bekas swapraja. Reformasi agraria juga dimaksudkan untuk memberikan akses rakyat terhadap tanah sebagai sumber ekonomi serta mengatasi sengketa dan konflik pertanahan yang ada.Dalam pandangan Kepala BPN tersebut ${ }^{3}$ pemberian tanah

3 Joyo Winoto, yang dilansir dalam Harian Kompas, 13 Desember 2006 dikutip dari situs Bappenas, <http://perpustakaan.bappenas.go.id/pls/ kliping/data access.show_file_clp?v_filename $=F 9767 / 8 . h t m>$, diakses tanggal 18 Desember, 2006. Berita serupa juga dimuat dalam berbagai surat kabar sejak bulan September 2006, dalam rangka Bulan Bakti Agraria memperingati tanggal 24 September saat berlakunya UUPA tahun 1960 diantaranya: 
bagi keluarga miskin di pedesaan diharapkan mampu meningkatkan taraf hidup mereka. Dari sekitar 40 juta penduduk miskin di Indonesia pada tahun 2006, sebanyak 67 persen di antaranya tinggal di pedesaan. Dari jumlah keluarga miskin tersebut, 90 persen menggantungkan hidupnya pada sektor pertanian. Adapapun model pembagian lahan akan berbeda untuk setiap daerah, bergantung pada kondisi dan ketersediaan lahan.

Terhadap isu rencana kebijakan redistribusi tanah tersebut telah menimbulkan komentar dan kritik antara lain yang diuraikan di bawah ini.

\section{Perhimpunan Bantuan Hukum Indonesia (PBHI)}

PBHI telah menyatakan sikap atas rencana pemerintah mengalokasikan lahan untuk rakyat/menjalankan "reforma Agraria" haruslah dalam kerangka reforma agraria sejati yang sesuai dengan asas-asas dan prinsip dari UUPA 1960. Sehingga tidak dijadikan sebagai alat legitimasi bagi dilaksanakannya reforma agraria berdasarkan keinginan modal dan kebijakan yang setengah-setengah.

Pandangan PBHI tersebut dengan pandangan yang agak sempit yaitu, karena dalam praktek landreform yang sesungguhnya tidak dikenal tanah untuk investor, tapi tanah untuk petani/penggarap (land to the tiller). Berdasarkan pandanganpandangannya tersebut $\mathrm{PBHI}$ menuntut:

TEMPO Interaktif, "Pemerintah Bagikan 9 Juta Hektar Tanah" Kamis, 28 September 2006 19:54 WIB < http://www.tempointeraktif.com/hg/ ekbis/2006/09/28/ brk,20060928-84977,id.html>.

a. Gorontalo (SIB), "8,I Juta Hektar Lahan Di Indonesia Akan Di Bebaskan Untuk Rakyat" <http://www.hariansib.com/content/view/147 99/38/>, diakses tanggal 25 November 2006.

b. Medan Bisnis, Program Reformasi Agraria: Pemerintah Bagikan 8,2 Juta Hektar Lahan buat Petani, <http://www.fspi.or.id/index.php?option $=$ com_content $\&$ task $=$ view $\&$ id $=357 \&$ Itemid $=62>$, diakses tanggal 29 September 2006.

4 PBHI, "Rencana Pemerintah Menjalankan "Reforma Agraria" di Indonesia", <http://www.pbhi.or.id/content.php?id=251\&id_tit=7>, diakses 19 Oktober 2006. 
a) Pemerintah segera menjalankan reforma agraria sejati yang diamanatkan oleh UUPA 1960;

b) Pemerintah Indonesia untuk segera menyelesaikan konflik agraria dengan mengutamakan keberpihakan dan keadilan kepada petani, nelayan dan masyarakat adat.

c) Negara untuk mencabut segala peraturan dan perundangan yang bertentangan dengan reforma agraria sejati dan dilaksanaknnya Undang-Undang Pokok Agraria 1960 secara konsekwen.

\section{Federasi Serikat Petani Indonesia (FSPI)}

FSPI memandang bahwa pelaksanaan reforma agraria menuntut penyusunan undang-undang baru yang merupakan turunan dari UUPA 1960, sehingga selain tidak melanggar struktur peruntukan, penguasaan, pemanfaatan, dan pengolahan tentang agraria, harus ada jaminan keberlanjutan dan kelestarian agraria tersebut.

Penataan struktur agraria yang berhubungan disektor pertanian dan kaum tani haruslah dimulai dari pelaksanaan program Landreform yaitu suatu upaya yang mencakup pemecahan dan penggabungan satuan-satuan usaha tani, dan perubahan skala pemilikan. Kemudian dilanjutkan dengan peningkatan kemampuan petani dengan berbagai programprogram pendidikan, upaya penyediaan subsidi, pemilikan teknologi pertanian, sistem distribusi/perdagangan yang adil, dan mendorong tumbuhnya organisasi-organisasi massa petani dan koperasi petani, serta infrastruktur lainnya.

Menurut pandangan $\mathrm{FSPI}^{5}$ langkah-langkah yang harus ditempuh oleh penyelenggara negara dalam menjalankan pembaruan agraria tersebut adalah:

1) Menjalankan reforma agraria haruslah sesuai dengan prinsip dan semangat dari jiwa UUPA 1960, yang dilaksanakan secara murni dan konsekwen.

5 FSPI. "Pandangan dan Sikap FSPI tentang Program Pembaruan tgraria Nasional". $\quad<$ http://www. fspi.or.id/index.php?option=com_content\&task=view\&id=366\& Itemid $=37>$. diakses 29 November 2006 . 
2) Pembatalan atau pencabutan terhadap seluruh produk undang-undang dan peraturan yang berkaitan dengan agraria, termasuk penghentian pembahasan RUU Penanaman Modal. Pembatalan atau pencabutan seluruh undang-undang dan peraturan yang berkaitan dengan agraria tersebut haruslah diikuti pula pembuatan undang-undang dan peraturan yang merupakan turunan dari UUPA 1960, sehingga tidak menjadi undang-undang dan peraturan yang sektoral dan tumpang tindih.

3) Untuk penyederhanaan dalam pelaksanaannya sehingga tidak terjadi tumpang tindih, maka departemen yang berkaitan dengan agraria haruslah dalam satu koordinasi, yang memiliki otoritas.

\section{B. Relevansi Rencana Redistribusi Dan Realisasinya Dengan Kondisi Hukum (UUPA Dan UU No.56/Prp/1960) Dan Peraturan Perundang-Undangan Yang Berlaku Bagi Program Landreform}

Berkenaan dengan rencana kebijakan redistribusi tanah tersebut tentunya secara hukum memerlukan legitimasi baik secara formil maupun materil. Secara formil tentunya harus ada paying hukum yang memadai "adequate"; dan secara materiil tentunya juga harus memperhatikan mekanisme dan sistem penyelenggaraan yang tepat dan efisien. Untuk itu di sini akan disampaikan review terhadap hukum positif yang berlaku dalam pelaksanaan program landreform yang sudah dimulai tidak lama setelah berlakunya UUPA,yaitu antara lain:

1) Landasan Idiil: Pancasila

2) Landasan Konstitusional: Pasal 33 ayat 3 UUD 1945

3) Landasan Operasional:

a) Undang-Undang Pokok Agraria (UUPA) Pasal 7, 10, 13, 15, 17 dan 53;

b) Undang-Undang (UU) Nomor 56/Prp/1960 tentang Penetapan Luas Tanah Pertanian;

c) UU Nomor 2/1960 tentang Perjanjian Bagi Hasil Tanah Pertanian;

d) Peraturan Pemerintah (PP) Nomor 224/1961 tentang Pelaksanaan Pembagian Tanah dan Pemberian Ganti Rugi; 
e) PP Nomor 41/1964 tentang Perubahan dan tambahan PP Nomor 224/1961;

f) PP Nomor 4/1977 tentang Pemilikan Tanah Pertanian secara Guntai (Absentee) Bagi Para Pensiunan Pegawai Negeri;

g) Peraturan Menteri Dalam Negeri (PMDN) Nomor 15/1974 tentang Pedoman Tindak Lanjut Pelaksanaan Land Reform;

h) Instruksi Presiden (Inpres) Nomor 13 tahun 1980 tentang Pedoman Pelaksanaan UU no. 2/1960;

i) Keputusan Presiden (Keppres) Nomor 54/1980 tentang Kebijaksanaan Pencetakan Sawah;

j) Peraturan Kepala Badan Pertanahan Nasional (BPN) Nomor 3/1991 tentang Pengaturan Penguasaan Tanah dan Obyek Land Reform Secara Swadaya;

Adapun di dalam pengaturan mengenai redistribusi tanah yang masih berlaku yaitu Peraturan Pemerintah Nomor 224 Tahun 1961, kiranya layak dijelaskan untuk memberikan analisis kemungkinan sebagai tolok ukur pelaksanan rencana kebijakan pemerintah membagi-bagi tanah pada akhir tahun 2006 yang lalu mengenai :

1) Tanah yang Menjadi Obyek Redistribusi

2) Pemberian Ganti Kerugian kepada Bekas Pemilik

3) Penerima Redistribusi

4) Persyaratan bagi Penerima Redsitribusi

5) Kewajiban Penerima Redistribusi

PP Nomor 224/1961 tersebut diatas telah mengatur pelaksanaan pembagian tanah dan pemberian ganti rugi sebagai ketentuan pelaksana dari Pasal 17 UUPA dan Pasal 2 dan 3 UU Nomor 56/Prp/1960. Namun karena buruknya kondisi politik dan ekonomi di Indonesia pada waktu itu tidak menguntungkan menyebabkan redistribusi tanah pertanian kurang berjalan sebagaimana yang diharapkan

Adanya sinyalemen kegagalan pelaksanaan landreform dan terkait dengan isu pelaksanaan redistribusi tanah, maka dapat diajukan beberapa permasalahan dari segi formalitas hukum yang mendasari pelaksanaan program tersebut, yaitu:

1) Selain UUPA dan UU No.56/Prp/1960, maka apakah peraturan pelaksananya PP Nomor 224 tahun 1961 secara 
materil masih relevan dengan kondisi (realitas) masyarakat saat ini?

2) Apabila sudah tidak relevan dan memerlukan pengaturan kembali dengan merevisi PP Nomor 224 tahun 1961, maka akan memerlukan waktu lebih lama dalam pelaksanaan program redistribusi tanah tersebut?

3) Bagaimana urusan koordinasi dengan pemerintah daerah dan bagaimana rumusan peran pemerintah daerah dalam hal ini?

4) Berkenaan dengan business core dan competency, maka instansi mana yang paling memiliki kewenangan, apakah BPN; atau Kementrian Dalam Negeri; ataukah pemda?

Selain itu telah juga ditetapkan Peraturan Kepala Badan Pertanahan Nasional (BPN) Nomor 3 Tahun 1991 tentang Pengaturan Penguasaan Tanah Obyek Land Reform Secara Swadaya. Redistribusi tanah obyek Land Reform yang semula hanya tanggung jawab Pemerintah kemudian dengan peraturan tersebut maka petani penerima redistribusi dapat turut berpartisipasi aktif.

Tujuan pengaturan penguasan tanah obyek Land Reform secara swadaya adalah untuk meningkatkan pembagian tanah kepada para petani penggarap yang sanggup berperan serta dalam pelaksanaan dan pembiayaannya dalam meningkatkan kesejahteraannya, sehingga pada akhirnya dapat tercapai:

a. Tertatanya penggunaan tanah obyek Land Reform dalam bidang tanah yang teratur disertai dengan prasarana jalan dan/atau saluran irigasi serta kemungkinan penyediaan areal untuk kawasan lindung dan fasilitas umum.

b. Terselenggaranya pembagian tanah yang merata tanpa menimbulkan perbedaan pemilikan tanah yang besar.

c. Tersedianya tanah yang dapat dimanfaatkan dan menjadi modal kehidupan petani yang dikelola secara kooperatif.

\section{Masalah Penanganan Sengketa Tanah-Tanah Ulayat}

Masalah sengketa pemilikan yang bernuansa historis ini dapat terjadi diantara orang-perorangan maupun antara badan hukum swasta dengan pihak instansi pemerintah atau dapat juga kombinasi diantara unsur-unsur tersebut. Nuansa historis ini diajukan berkaitan dengan pemilikan yang terkait dengan fakta sejarah adanya pluralisme hukum tanah yang pernah berlaku sejak jaman penjajahan; juga unsur 
keturunan (turun-temurun); penerapan sistem pembuktian (tertulistidak tertulis) yang diterapkan dalam hukum acara ${ }^{6}$.

Masalah yang signifikan dan relevan adalah berkaitan dengan Hak Ulayat Masyarakat hukum adat yang kembali diakomodasikan dalam berbagai tingkatan peraturan perundang-undangan ${ }^{7}$.

Pengakuan dan perlindungan terhadap masyarakat adat dalam peraturan perundang-undangan secara umum diatur dalam Pasal 18b, dan Pasal 28I Undang-undang Dasar 1945. Kedua Pasal tersebut dalam pengakuan dan perlindungan mensyaratkan dengan "sepanjang sesuai dengan perkembangan masyarakat dan Negara Kesatuan Republik Indonesia. sesuai dengan perkembangan jaman dan peradaban".

Pengakuan dan perlindungan terhadap masyarakat adat sebagai suatu unit komunitas berdasarkan peraturan perundang-undangan di tingkat pelaksanaan berdasarkan pernah diatur melalui Peraturan Menteri Dalam Negeri No. 3 Tahun 1997 tentang Pemberdayaan dan Pelestarian serta Pengembangan Adat Istiadat, Kebiasaan-kebiasaan Masyarakat, dan Lembaga Adat di Daerah ${ }^{8}$

\footnotetext{
${ }^{6}$ Hingga saat ini khususnya di DKI Jakarta masih banyak terjadi sengketa tanah berkaitan dengan eks.hak-hak atas tanah Belanda (ex-eigendom verponding, ex-tanah partikelir) contoh lain kasus rencana pembangunan bandar udara di atas Tanah Hebe-Ohee di Papua dan di daerah lain yang terkait dengan kasus-kasus tanah milik penduduk yang secara alami mendiami lokasi tertentu yang akan dijadikan proyek pembangunan yang berskala ekonomi besar seperti pertambangan, perkebunan. waduk, kehutanan, transmigrasi. dll.
}

${ }^{7}$ Pengaturan Masyarakat hukum adat dan Hak Ulayat dapat dilihat mulai dari UUD 1945 hingga peraturan kepala desa. Dua argumen reformasi yang berkembang menjelang pemberlakukan UU nomor 41 tahun 1999. yaitu: argumen pertama, menuntut pengakuan dan pengembalian hak atas hutan dan pemulihan hak yang telah dirampas selama ini serta klasifikasi ulang terhadap hutan negara. Terhadap argumen ini Franz von Benda-Beckmann memandangnya sebagai bukan pengakuan atas hukum (adat) mereka atau kembali ke cara-cara lama yang terutama diinginkan masyarakat. melainkan pengakuan dan penghapusan ketidakadilan historis serta kekuasaan yang sah dan diakui (legitimate) untuk mengatur urusan mereka sendiri; dan argumen kedua adalah tuntutan distribusi ulang atas akses terhadap sumber daya hutan dan pendapatan dari hutan sebagai sarana untuk mengalihkan ekonomi dari kendali segelintir elite menuju jaringan bisnis berskala kecil dan menengah yang diorganisasikan sebagai koperasi

8 Namun demikian pengakuan dan perlidungan itu telah mereduksi lingkup kehidupan masyarakat adat kerena dalam konsep pemberdayaan dan pelestarian yang diatur hanya mengenai aspek yang sempit yaitu aspek budaya yang di identifikasikan dalam wujud adat istiadat, kebiasaan-kebiasaan, dan lembaga adat. Pengaturan terhadap hubungan dan 
Sebagai pengaturan lebih lanjut, masyarakat adat juga diakui dalam Ketetapan MPR Nomor XVII/MPR/1998 tentang Hak Azasi Manusia yang kemudian ditampung dalam UU Hak Azasi Manusia No. 39 Tahun 1999

Pada permasalahan khusus menyangkut penyelesaian masalah tanah-tanah Hak Ulayat telah di atur pula di dalam Peraturan Menteri Negara Agraria/Kepala BPN No. 5/1999 memberikan sejumlah kriteria dasar untuk memastikan keberadaan hak ulayat masyarakat adat (yaitu keberadaan Tanah Ulayat). Disebutkan bahwa masyarakat mempunyai hak atas tanah bilamana:

1) Masyarakat yang bersangkutan masih terikat oleh hukum adat sebagai sebuah masyarakat spesifik yang mengakui dan menerapkan hukum adat dalam kehidupan sehari-hari;

2) Terdapat tanah ulayat yang menjadi lingkungan hidup masyarakat adat yang bersangkutan dan menjadi tempat pemenuhan kebutuhan hidup mereka sehari-hari;dan

3) Terdapat hukum adat yang mengatur pengelolaan dan pemanfaatan tanah ulayat yang bersangkutan, yang dipatuhi oleh masyarakat adat tersebut.

Pasal 3 PMNA No.5/1999 ini menetapkan sejumlah keadaan yang mengakibatkan punahnya hak atas tanah adat, yaitu:

1) Bidang tanah yang bersangkutan telah dikuasai oleh perorangan atau badan

2) hukum dengan suatu hak berdasarkan UUPA; atau

3) Bidang tanah yang bersangkutan telah diambilalih atau dibebaskan oleh lembaga pemerintah, badan hukum, atau perorangan sesuai dengan peraturan perundang-undangan dan prosedur yang berlaku.

akses masyarakat adat dengan sumber daya alam yang sudah ada tidak diperhatikan dalam pengertian tidak mendapat pengaturan yang komperehensif.

Hal tersebut tampak dari adanya empat dari 11 definisi istilah yang amat signifikan dengan pemberdayaan masyarakat adat tidak dijabarkan dalam Pasal-Pasal selanjutnya. Adapun istilah yang dimaksud adalah istilah lembaga adat, wilayah adat, hak adat, hukum adat. 


\section{Polemik mengenai Desentralisasi dan Kewenangan Pengelolaan Pertanahan (Pengelolaannya Apakah Ada di Pusat Saja; atau Di daerah Saja; atau Ada Pembagian Jenis Wewenang dalam Pengelolaan Tanah Di pusat Ada. dan Di daerah Ada Juga?)}

Pasca reformasi yang ditandai dengan era otonomi daerah dengan berlakunya UU Nomor 22 tahun 1999 dan UU Nomor 25 tahun 1999?, telah juga menimbulkan berbagai masalah. Adapun permasalahan yang timbul dapat dikelompokkan menjadi konflik horizontal dan konflik vertikal. Konflik horisontal ${ }^{10}$ yang sempat dan masih berlanjut? Adalah berkaitan dengan kewenangan di dalam bidang pertanahan yang melibatkan antara lain Badan Pertanahan Nasional dan Departemen Dalam Negeri. Hal itu dapat dilihat dengan adanya beberapa produk Keputusan Presiden yang berturut-turut namun berbeda arah pelaksanaan otonomi pertanahan yang satu kepada Depdagri kemudian yang baru kepada BPN (Keppres Nomor 34/2003). Konflik vertikal adalah yang terjadi antara pemerintah pusat dengan propinsi; propinsi dengan kabupaten".

Sejak masa desentralisasi pemerintahan daerah dimulai dengan berlakunya UU No.22 tahun 1999 dan kemudian direvisi dengan UU No.34 tahun 2004, maka dimulailah prosesi penyerahan berbagai kewenangan yang selama ini berada di tangan pemerintah pusat kepada pemerintah daerah. Namun dalam rangka penyerahan urusan kewenangan pertanahan sebagaimana diatur di dalam UU No.34 tahun 2004, ternyata menimbulkan polemik menyusul di tetapkannya Peraturan Presiden Nomor 10 tahun 2006.

\footnotetext{
9 Pada tahun 2004 kedua undang-undang tersebut telah diganti dengan UU Nomor 32 tahun 2004 dan UU Nomor 33 tahun 2004

${ }^{10}$ Konflik horisontal yang sempat terjadi adalah antara dua kabupaten yang berebut penentuan batas wilayah seperti antara kabupaten Kutai Timur dengan Kutai Kertanegara; antara kecamatan dengan kecamatan yang dalam tahap pemekaran.
}

$"$ Yang terlihat konflik antara pemerintah pusat dengan propinsi adalah kasus Kawasan Gelora Senayan selama ini dikuasai oleh Setneg-RI (dengan Propinsi DK1) yang masih terus berlanjut berkenaan dengan otonomi di propinsi DKI Jakarta dengan UU nomor 34 tahun 2000 yang memberikan peluang kepada pemerintah propinsi DKI untuk mengelola tanah di wilayahnya berkaitan dengan kewenangan umum pemerintahan propinsi. 
Akibatnya persaingan pelaksanaannya di tingkat teknis terlihat di berbagai daerah yang masih terdapat Kantor Pertanahan (instansi vertikal BPN) namun juga ada Dinas Pertanahan Kabupaten/kota sebagai pelaksanaan otonomi daerah.

Protes dan kritik antara lain diberikan oleh para stake holders yang berkepentingan dengan masalah-masalah pelaksanaan otonomi daerah: $:^{12}$

1) Semua pemerintahan provinsi yang tergabung dalam APPSI (Asosiasi Pemerintahan Provinsi Seluruh Indonesia) sepakat untuk mengajukan juducial review terhadap Perpres (Peraturan Presiden) Nomor 10 Tahun 2006 tentang BPN (Badan Pertanahan Nasional). Kesepakatan untuk mengajukan judicial review itu dicapai dalam rapat APPSI yang dipimpin ketuanya, Gubernur DKI Jakarta Sutiyoso. Menurut Sutiyoso, kesepakatan ini sebagai tindak lanjut dari rekomendasi yang dikeluarkan dalam rapat kerja nasional APPSI di Mataram beberapa waktu lalu.

2) Menurut Sutiyoso Perpres 10/2006 itu bertentangan dengan prinsip otonomi daerah, karena persoalan pertanahan sepenuhnya sudah merupakan wewenang pemerintah daerah, baik provinsi, kabupaten maupun kota, sebagaimana amanat UU 32/2004 tentang Pemerintahan Daerah.

3) Selain itu, keberadaan Perpres dinilai sudah mendahului lahirnya PP (Peraturan Pemerintah) tentang Pembagian Urusan Pemerintahan, antara Pemerintah, Pemerintah Daerah Provinsi dan Pemerintah Daerah Kabupaten/Kota sebagai pengganti PP No. 25 tahun 2000 tentang Pembagian Kewenangan Pemerintah dengan Pemerintah Daerah Otonom.

Sebab itulah, sejak keluarnya Perpres tersebut, APPSI sudah mengingatkan kepada Presiden Susilo Bambang Yudhoyono untuk menangguhkan pelaksanaannya. Bahkan Presiden sudah berjanji untuk melakukan revisi. Tetapi yang menjadi aneh dan menggelikan, adalah tindakan dari Kepala BPN Joyowinoto, yang sudah melantik 700 pejabat eselon II untuk ditempatkan di berbagai provinsi dan

\footnotetext{
$12<$ http://www.bangyos.com/id_berita-isi.php?cid=1\&id=274>, diakses Rabu, 26
} Juli 2006. 
kabupaten/kota untuk ditempatkan sebagai Kepala kantor Wilayah BPN.

\section{DPRD Kota Bekasi, Jawa Barat}

Ketua Komisi A DPRD Kota Bekasi, Hasnul Kholid Pasaribu, mempertanyakan kejelasan status Badan Pertanahan Nasional (BPN) Kota Bekasi. Menurutnya, BPN saat ini masih mendua karena di satu sisi bertanggung jawab ke Pemerintah Pusat, di sisi lain ke Pemkot Bekasi. "Coba sekarang ini Kepala Kantor Pertanahan pergi ke Jakarta, namun Pemkot Bekasi tidak tahu dan mungkin tidak dilapori," ujarnya di Bekasi, Selasa $(19 / 8) \cdot{ }^{13}$

Sementara itu, Sekretaris Komisi A, Qisas Rachman, ketika dimintai komentarnya soal status BPN juga sependapat dengan Hasnul Kholid Pasaribu. Pertanyaan itu sebagai konsekuensi diajukannya perubahankelembagaan di jajaran Pemkot Bekasi ke DPRD setempat, namun tidak mengikutsertakan BPN.

Adapun kelembagaan yang diajukan Pemkot Bekasi sebanyak 23 organisasi perangkat daerah antara lain, penambahan lembaga Asisten Daerah (Asda), Dinas Kebersihan, Pertamanan dan Pemakaman. Selanjutnya, Lembaga Teknis Kantor Pemadam Kebakaran, Bakukeda (Badan Kekayaan dan Keuangan Daerah) akan diganti menjadi Badan Pendapatan Daerah.

\section{Asosiasi Pemerintah Kota Seluruh Indonesia (Apeksi) Komisariat Sumatera Bagian Selatan ${ }^{14}$}

Asosiasi Pemerintah Kota Seluruh Indonesia (Apeksi) Komisariat Sumatera Bagian Selatan meminta pemerintah pusat segera menyerahkan urusan pertanahan kepada daerah otonom. Penyerahan urusan pertanahan itu penting agar semua kota dan kabupaten mudah mengatur alokasi lahan guna perencanaan tata ruang. Hal itu dikemukakan koordinator Apeksi Komisariat

13.DPRD Kota Bekasi Pertanyakan Kejelasan Status BP. ", <http://www.kompas. com/metro/news/(0308/19/102947.htm>, diakses 19 Agustus 2006.

14.. Apeksi Sumhagsel Tuntut Otonomi Pertanahan". http://kompas.com/verl/ nusantara/0611/14/115112.htm> diakses. Selasa $19 \mathrm{Agustus} 2006$. 
Sumbagsel dan Wali Kota Pangkal Pinang, Zulkarnain Karim, dalam penutupan Musyawarah Apeksi Sumbagsel, Selasa 14 November 2006 di Pangkal Pinang.

Untuk memudahkan penyerahan urusan pertanahan, Apeksi bersama dengan asosiasi pemerintah kabupaten dan asosiasi pemerintah desa sudah mengajukan judicial review atas peraturan presiden mengenai tugas dan fungsi BPN. Judicial review itu untuk memudahkan ditetapkannya peraturan pelaksanaan UndangUndang Nomor 32 tahun 2004 mengenai Pemerintahan Daerah.

Dalam peraturan pelaksanaan itu, akan dipertegas kewenangan pemerintah daerah otonom, yang salah satunya adalah urusan pemerintahan. Peraturan itu akan membuat kantor BPN di daerah akan dilebur menjadi Dinas Pertanahan, di bawah wali kota dan bupati. Para staf Dinas Pertanahan, kata Zulkarnain, akan direkrut dari staf BPN daerah, sedangkan, semua aset, data, peta dan semua peralatan kerja BPN daerah juga akan menjadi milik Dinas Pertanahan daerah.

Selain itu dalam pandangan Apeksi juga penyerahan kewenangan kepada daearah akan memudahkan pengaturan tata ruang kota, penyerahan kewenangan pertanahan di daerah akan membuat pelayanan pembuatan sertifikat bagi masyarakat semakin cepat dan murah. Di sisi lain, pemasukan bagi daerah dari urusan pertanahan juga semakin besar karena tidak tersedot ke pemerintah pusat.

\section{Asosiasi DPRD Kota Seluruh Indonesia (Adeksi) ${ }^{15}$}

Asosiasi DPRD Kota Seluruh Indonesia (Adeksi) secara tegas menolak Peraturan Presiden (Perpres) No. 10 Tahun 2006 Tentang Badan Pertanahan Nasional (BPN). Penolakan ini didasarkan karena Perpres tersebut telah mengurangi kewenangan daerah serta substansi Pasal-Pasal Perpres tersebut bertentangan dengan UU No. 32 Tahun 2004 tentang Pemerintahan Daerah. Pada Pasal 2 Perpres No. 10/2006 disebutkan, Badan Pertanahan Nasional (BPN) melaksanakan tugas pemerintahan dibidang pertanahan secara nasional, regional dan sektoral. Kemudian pada Pasal

15 "Adeksi menolak Perpres No. 10 Tahun 2006, tentang Badan Pertanahan Nasional". $\quad<$ http://www.adeksi.or.id/detail/detailpressrelease.php?id=6>, diakses 19 Desember 2006. 
berikutnya diterangkan mengenai 21 fungsi BPN, antara lain pengaturan dan penetapan hak atas tanah, pembinaan dan pelayanan administrasi umum bidang pertanahan, serta pelaksanaan penatagunaan tanah, reformasi agraria dan penataan wilayah khusus.

Pasal-pasal tersebut mengindikasikan bahwa daerah tidak mempunyai kewenangan atas pertanahan, karena semua yang berhubungan dengan pertanahan diatur dari pusat. Padahal secara logika hukum bidang pertanahan di daerah berkaitan dengan tata ruang wilayah dimana yang mengetahui persis kondisi wilayah serta persoalan pertanahan adalah daerah itu sendiri. Oleh karena itu bila pertanahan diserahkan kewenangannya ke pusat hal ini akan menimbulkan persoalan yang serius dikemudian hari.

Pertanahan sampai saat ini masih selalu menjadi persoalan di daerah. Hal ini karena di daerah tidak ada kantor dinas pertanahan mengingat semua urusan tanah diatur dari pusat (BPN) melalui kantor wilayah BPN yang ada di kabupaten/kota. Akibatnya persoalan-persoalan pertanahan di daerah tidak kunjung selesai. Seharusnya urusan dan kewenangan pertanahan tidak diserahkan semuanya kepada BPN seperti yang diatur dalam Perpres No. 10/2006. Karena dikhawatirkan mereka tidak mampu menyelesaikan masalah pertanahan seperti yang diharapkan masyarakat.

Sehubungan dengan persoalan pertanahan tersebut, Adeksi telah mengeluarkan pernyataan sikap sebagai berikut :

a) Menolak dikeluarkannya Perpres No. 10 Tahun 2006 tentang Badan Pertanahan Nasional, karena Perpres tersebut sebagai bukti tidak adanya kewenangan daerah atas pertanahan sebagaimana amanat UU 32/2004 tentang Pemerintahan Daerah.

b) Mengharapkan segera dibentuk badan konsultasi untuk memfasilitasi antara pusat dan daerah dalam proses pengembalian kewenangan atas pertanahan kepada daerah.

c) Mengajak komponen daerah untuk secara serius berkoordinasi dan bekerjasama dalam rangka mewujudkan desentralisasi bidang pertanahan di daerah sebagaimana cita-cita otonomi daerah.

d) Menuntut kepada pemerintah agar konsekuen dan serius dalam menjalankan politik desentralisasi sesuai semangat otonomi daerah. 
e) Mendesak harmonisasi dan sinkronisasi antar lembaga pemerintah bidang sektoral dalam menerapkan prinsip-prinsip desentralisasi.

Penjelasan menganai penyerahan kewenangan bidang pertanahan menurut Undang-Undang No. 32 Tahun 2004 dapat dijelaskan berikut ini. Adapun kewenangan yang menjadi urusan Pemerintahan Daerah Propinsi, Kabupaten/Kota ada yang merupakan urusan wajib dan ada yang bersifat pilihan. Yang merupakan urusan wajib, disebut dalam Pasal 13 ayat (1) dan Pasal 14 ayat(1). Sepanjang yang mengenai bidang pertanahan, urusan yang bersifat wajib meliputi "pelayanan pertanahan", yang akan diatur lebih lanjut dengan Peraturan Pemerintah, yang hingga sekarang belum ada.

Pasal 10 ayat (1) dan (2) menyatakan, bahwa: "Pemerintahan Daerah menyelenggarakan urusan pemerintahan yang menjadi kewenangannya, kecuali urusan pemerintahan yang oleh undangundang ini ditentukan menjadi urusan Pemerintah. Dalam menyelenggarakan urusan pemerintahan yang kewenangan daerah sebagaimana dimaksud dalam ayat (1), pemerintahan daerah menjalankan otonomi seluas-luasnya untuk mengatur dan mengurus sendiri urusan pemerintahan berdasarkan asas otonomi dan tugas pembantuan".

Perlu diperhatikan, bahwa urusan kewenangan pemerintahan tersebut tidak khusus/tidak hanya mengenai pertanahan. Maka masih menjadi persoalan, apakah yang dinyatakan dalam Pasal 10 ayat (2) tersebut seluruhnya berlaku juga terhadap urusan pelayanan pertanahan, yang disebut dalam Pasal 13 dan 14

Pasal 10 ayat (5) menetapkan bahwa "selain urusan pemerintahan yang disebut dalam ayat (3) diatas", masih ada urusan-urusan lain, yang kewenangannya ada pada Pemerintah Pusat. Kiranya ini adalah urusan yang ditentukan secara khusus oleh berbagai undang-undang.Diantara urusan-urusan lain itu termasuk juga urusan bidang pertanahan, yang oleh Pasal 33 ayat (3) UUD RI 1945 dan Pasal 2 UUPA kewenangannya ditugaskan kepada Negara.

\section{Beberapa Pendapat Lain}

Susie Berindra dalam tulisannya bertajuk "Pertanahan Kewenangan yang Masih Diperebutkan" dalam harian Kompas, 
Jumat, 16 Juni 2006 memberikan highlight dari hasil Rapat Kerja Nasional Asosiasi Pemerintah Provinsi Seluruh Indonesia, bulan Mei 2006. APPSI telah meminta pemerintah memberi kewenangan bidang pertanahan kepada daerah, sesuai Undang-Undang Nomor 32/2004 tentang Pemerintahan Daerah.

UU No 32/2004 telah dua tahun dilaksanakan. Namun, sampai sekarang pembagian kewenangan antara pemerintah pusat dan daerah belum kunjung jelas. Salah satunya bidang pertanahan yang masih diwarnai tarik-menarik pusat dan daerah. Pusat ingin menguasai semua kewenangan di bidang pertanahan, sementara pemerintah daerah ingin mendapat bagian urusan pertanahan.

Dalam UU No 32/2004, ada enam kewenangan pemerintahan pusat dan 30 kewenangan yang bisa dilaksanakan pemerintahan daerah. Pusat punya wewenang dalam bidang politik luar negeri, pertahanan, keamanan, hukum, moneter, dan agama. Salah satu kewenangan pemerintah daerah adalah dalam bidang pelayanan pertanahan. Akan tetapi, dalam Peraturan Pemerintah Nomor 25 Tahun 2000 tentang Kewenangan Pemerintah dan Kewenangan Provinsi sebagai Daerah Otonom, yang merupakan turunan UU No 32/2204, tidak satu pun yang menyebut pemda punya kewenangan pertanahan.

Belum lagi, revisi PP No 25/2000 diselesaikan Departemen Dalam Negeri, tiba-tiba muncul Peraturan Presiden Nomor 10 Tahun 2006 tentang Badan Pertanahan Nasional (BPN), 11 April 2006. Pasal 2 Perpres No 10/2006 menyebutkan, BPN bertugas melaksanakan tugas pemerintahan di bidang pertanahan secara nasional, regional dan sektoral. Kemudian Pasal berikutnya, menyebut BPN memiliki 21 fungsi. Beberapa fungsi itu adalah pengaturan dan penetapan hak atas tanah, pembinaan dan pelayanan administrasi umum bidang pertanahan serta pelaksanaan penatagunaan tanah, reformasi agraria dan penataan wilayah-wilayah khusus.

Dalam aturan sebelumnya, Keputusan Presiden Nomor 95/2000 tentang BPN, disebutkan bahwa tugas BPN adalah pengaturan peruntukan, persediaan dan penggunaan tanah, pengaturan hubungan hukum antara orang dan tanah serta pengaturan hubungan hukum antara orang dan perbuatan hukum berkaitan dengan tanah. Di dalam Keputusan Presiden Nomor 95/2000 itu menyebut BPN mempunyai enam fungsi.

Perpres No 10/2006 ini tentu membuat berang kalangan pemerintahan daerah, baik di tingkat provinsi maupun kabupaten/kota. Dalam Rapat Koordinasi Asosiasi dan Badan Kerja Sama seluruh 
Indonesia dengan Depdagri, mereka memprotes Perpres No 10/2006 yang tidak memberi napas otonomi daerah.

Itu sebabnya, APPSI dalam rapat Mei 2006 merekomendasi prakarsa pengajuan konsep perubahan UU No 5/1960 tentang Pokokpokok Agraria agar selaras dengan asas desentralisasi, demi menampung tuntutan pelayanan pertanahan akibat perkembangan jumlah penduduk, kemajuan ilmu pengetahuan dan teknologi, perubahan tata ruang, kepastian hak-hak atas tanah, termasuk hak ulayat/adat.

Mantan Sekretaris Utama BPN Toto Sumiyoto dalam tulisannya berjudul Kewenangan Bidang Pertanahan dalam Rangka Pelaksanaan Otonomi Daerah mengatakan, dengan diberlakukan UU 22/1999 tentang Pemerintahan Daerah, sistem pemerintahan berubah signifikan, dengan memberi kewenangan luas, nyata, dan bertanggung jawab kepada daerah secara proporsional. Karena itu, perlu pembagian kewenangan yang jelas antara pemerintah pusat dengan provinsi dan kabupaten/kota.

Toto mengusulkan pemerintah provinsi diberi kewenangan perencanaan penatagunaan tanah provinsi, perencanaan penatagunaan pertanahan antara dua kabupaten/kota, dan penyelesaian penetapan hak ulayat antara dua kabupaten/kota. Adapun pemerintah kabupaten/kota diberi kewenangan izin lokasi, pengaturan dan peruntukan tanah, penyelesaian masalah sengketa tanah garapan atas tanah negara, penguasaan pendudukan tanah tanpa izin dari yang berwenang dan penyelesaian ganti rugi untuk pengadaan tanah.

Di sisi lain, Sekjen Konsorsium Pembaruan Agraria Usep Setiawan mengungkapkan tarik ulur kewenangan bidang pertanahan antara pusat dan daerah ini sebenarnya tidak terlalu penting. Pembagian kewenangan yang jelas akan menjadi percuma, tanpa reformasi agraria dengan perubahan struktur organisasi pemerintahan. Berbagai persoalan sengketa pertanahan tetap saja tidak bisa diselesaikan.

Menurut Usep reformasi agraria membutuhkan kebijakan nasional. Karena itulah, tidak bisa semua kewenangan bidang pertanahan diberikan kepada daerah. Sebaiknya pemerintah membagi kewenangan secara proporsional dan menghentikan tarik-menarik kepentingan pusat dan daerah, lupakan kepentingan internal pemerintahan. Selain itu harus dimulai tahap memikirkan solusi terbaik kondisi agraria di lapangan sehingga berbagai persoalan agraria yang banyak memakan korban dapat segera diselesaikan. 


\section{A. Penjelasan Perihal Pendelegasian Kewenangan Bidang Pertanahan}

Menyikapi polemik desentralisasi kewenangan di bidang pertanahan tersebut, dengan memperhatikan Pasal 33 ayat (3) dan beberapa ketentuan Undang-Undang yang merupakan hukum positif, maka dapat diberikan penjelasan sebagai berikut:

\section{Kewenangan Pemerintah Pusat}

Dengan memperhatikan ketentuan Pasal 33 ayat (3) UUD 1945, yang secara konstitusional memberikan wewenang dalam rangka mengelola pertanahan dan dalam arti luas terhadap sumber kekayaan alam di Indonesia, jelas dan dapat ditafsirkan bahwa dalam kerangka pengaturan masalah pertanahan pada dasarnya merupakan kewenangan Negara RI.

Selanjutnya dalam rangka pelaksanaan lebih lanjut kewenangan negara tersebut, dengan memperhatikan ketentuan Pasal 2 dan Pasal 14 UUPA, maka kewenangan negara dalam bidang pertanahan adalah meliputi:

a) mengatur dan menyelenggarakan peruntukan, penggunaan, persediaan dan pemeliharaan bumi, air dan ruang angkasa tersebut;

b) menentukan dan mengatur hubungan-hubungan hukum antara orang-orang dengan bumi, air dan ruang angkasa,

c) menentukan dan mengatur hubungan-hubungan hukum antara orang-orang dan perbuatan-perbuatan hukum yang mengenai bumi, air dan ruang angkasa.

Berdasarkan ketentuan Pasal 2 ayat (2)UUPA tersebut, maka untuk saat ini berkenaan dengan adanya desentralisasi kewenangan kepada pemerintah daerah, sesungguhnya kewenangan tersebut masih relevan. Hal itu karena kewenangan yang diatur di dalam Pasal 2 ayat (2) tersebut sebagai kewenangan dalam bentuk kaedah politik pertanahan yang dimaksudkan menjabarkan Pasal 33 ayat (3) UUD 1945. secara sistematis jika ditafsirkan dengan desentralisasi adalah relevan dengan ketentuan Pasal 2 ayat (4) UUPA:

Hak menguasai dari Negara tersebut diatas pelaksanaannya dapat dikuasakan kepada daerah- 
daerah swatantra dan masyarakat-masyarakat hukum adat, sekedar diperlukan dan tidak bertentangan dengan kepentingan nasional, menurut ketentuanketentuan Peraturan Pemerintah.

Pasal 2 ayat (4) tersebut membuka kemungkinan pelaksanaan desentralisasi kewenangan tersebut dan memerlukan perumusan lebih lanjut dalam kerangka pelaksanaan UU Nomor 34 tahun 2004 yang sementara ini dirumuskan dalam lingkup "pelayanan dalam bidang pertanahan".

\section{Kewenangan Pemerintah Daerah}

Dalam perspektif Hukum Tanah nasional (UUPA) Pemerintah dalam rangka sosialisme Indonesia membuat suatu rencana umum $^{16}$ mengenai persediaan, peruntukan dan penggunaan bumi, air dan ruang angkasa serta kekayaan alam yang terkandung didalamnya:

a) untuk keperluan Negara,

b) untuk keperluan peribadatan dan keperluan suci lainnya, sesuai dengan dasar Ketuhanan Yang Maha Esa;

c) untuk keperluan pusat-pusat kehidupan masyarakat, sosial, kebudayaan dan lain-lain kesejahteraan;

d) untuk keperluan memperkembangkan produksi pertanian, peternakan dan perikanan serta sejalan dengan itu;

e) untuk keperluan memperkembangkan industri, transmigrasi dan pertambangan.

Berdasarkan rencana umum tersebut dan mengingat peraturan-peraturan yang bersangkutan, Pemerintah Daerah mengatur persediaan, peruntukan dan penggunaan bumi, air serta ruang angkasa untuk daerahnya, sesuai dengan keadaan daerah masing-masing ${ }^{17}$.

${ }^{16}$ Terminologi "membuat suatu rencana umum", sebagai kewenangan pemerintah (pusat) dalam Pasal 14 UUPA memang tepat dalam menjabarkan Pasal 33 ayat (3) UUD 1945, kewenangan tersebut dalam level politik pertanahan seperti di dalam Pasal 2 ayat (2) UUPA. 
Sementara di dalam UU Nomor 32 tahun 2004, di dalam Pasal 13 dan 14, terlihat dua jenis kewenangan dalam bidang pelayanan pertanahan dan perencanaan, pemanfaatan dan pengawasan tata ruang pada level propinsi dan kabupaten $/ \mathrm{kota}^{18}$.

Berdasarkan pemahaman terhadap ketentuan UUPA dan UU Nomor 32 tahun 2004, tersebut maka secara yuridis dapat dijelaksan mengenai kewenangan di bidang pertanahan:

1) Lingkup kewenangan pemerintah pusat, adalah dalam lingkup membuat blue print politik/kebijakan pertanahan nasional sebagai pelaksanaan Pasal 33 ayat (3) UUD 1945 dalam lingkup substansi pengaturan yang sudah ada di dalam Pasal 2 dan Pasal 14 UUPA;

2) Ada juga lingkup kewenangan pemerintah daerah, dapat disinkronkan berkenaan dengan pelaksana delegasi kewenangan pemerintah pusat (dapat ditafsirkan dalam bidang pelayanan pertanahan) dan membuat rencana umum tata ruang wilayah (RUTR) sebagai kewenangan yang linear dengan kewenangan pemerintah pusat. Dalam lingkup kewenangan ini pemerintah daerah tetap tunduk pada pedoman umum kebijakan/politik pertanahan nasional di dalam Pasal 33 ayat (3) UUD 1945 jo. Pasal 14 dan Pasal 2 UUPA. Hal itu sebagai konsekuensi format negara kesatuan yang memberikan kedaulatan penuh pada NKRI dalam segala aspek. Pemerintah Pusat sebagai organisasi kekuasaan adalah penyelenggara kekuasaan negara, sedangkan pemerintah daerah tidak lain hanya menjalankan

${ }^{17}$ Ketentuan Pasal 14 ayat (2) UUPA, terlihat adanya pelimpahan kepada daerah untuk juga membuat politik pertanahan di daerahnya masing-masing sesuai kondisi tiap-tiap daerah dan adanya keharusan politik pertanahan tersebut dituangkan dalam bentuk Peraturan Pemerintah Daerah (PERDA) baik di level propinsi, kabupaten/kota. Ketentuan Pasal 14 ini memiliki perbedaan dengan Pasal 2 UUPA yang bersifat hubungan vertikal (sub-ordinasi); namun di dalam Pasal 14 ini ada kewenangan linear pada level pemerintahan masing-masing (Pemerintah pusat - pemerintah daerah), sekalipun terkandung sub-ordinasi namun hanya pada lingkup substansi politik/kebijakan rencana penggunaan tanah secara normatif.

${ }^{18}$ Namun kewenangan pemerintah propinsi dalam pelayanan pertanahan dibatasi sejauh pelayanan pertanahan yang bersifat lintas kabupaten/kota saja, selbihnya merupakan kewenangan pemerintah kabupaten/kota, yang dipertegas di dalam Pasal 14 undang-undang tersebut. 
pemerintahan sebagai pelimpahan kekuasaan negara dari pemerintah pusat. ${ }^{19}$

Demikianlah maka sebenarnya polemik desentralisasi kewenangan pertanahan dapat dijelaskan dan tidak perlu berkepanjangan, sepanjang dilandasi niat luhur para penyelenggara negara dan seyogyanya rumusan di dalam revisi PP 25/2000, tentang Pembagian Kewenangan Pemerintahan pada pemerintah pusat dan daerah, akan memuat substansi yang tidak meninggalkan prinsip-prinsip tersebut di atas.

\section{Penutup}

Dari uraian mengenai masalah-masalah aktual dalam rangka reformasi agraria di Indonesia pada bagian terdahulu, maka dapat disampaikan resume sekaligus sebagai kesimpulan sebagai berikut:

1. Reformasi agraria di Indonesia sesungguhnya telah dimulai sejak tahun 1960 secara normatif namun dalam realisasinya mengalami keterlambatan, berbagai hambatan ideologis, politis dan pada akhirnya program landreform di Indonesia termasuk gagal dibandingkan dengan Jepang dan Taiwan;

2. Adanya isu kebijakan pemerintah untuk melakukan landreform, khususnya melakukan redistribusi tanah kepada rakyat miskin yang meliputi tanah seluas 8,5 juta ha $(60 \%$ untuk petani tuna kisma); dan sisanya $40 \%$ untuk perumahan dengan jangka waktu hak 100 tahun memerlukan pemikiran dan perumusan kembali terhadap ketentuan hukum positif yang berlaku. Hal itu agar pelaksanaan redistribusi tanah yang digagas pemerintahan SBY saat ini tidak mengulangi kegagalan pelaksanaan redistribusi yang telah terjadi di dasawarsa 1960-an. Hal ini dengan mempertimbangkan beberapa isu kontemporer mengenai:

a. masalah mendasar dengan terus bertambah meningkatnya angka kemiskinan di perkotaan dan perdesaan;

${ }^{19}$ Sebagai Pemahaman kontekstual materi Undang-Undang Nomor 32 tahun 2004 yang secara sistematik telah mengatur di dalam BAB III dan BAB IV, berkenaan dengan Pembagian Kewenangan dan penyelenggaraan Pemerintahan dan dapat diterapkan dalam menguraikan penjelasan terhadap polemik desentralisasi pertanahan yang dibahas ini 
b. masalah penyelesaian sengketa tanah-tanah ulayat masyarakat hukum adat yang belum tuntas;

c. masalah sengketa desentralisasi kewenangan bidang pertanahan yang belum juga tuntas 


\section{Daftar Pustaka}

\section{Buku}

Harsono, Boedi., Hukum Agraria Indonesia, Bagian Pertama, Jilid I, Jakarta: Penerbit Djambatan, Edisi Revisi 1999.

Hutagalung, Arie S., et al., Asas-asas Hukum Agraria, bahan kuliah Hukum Agraria FHUI, 1997.

Indrawati, Sri Mulyani. Dr., "Krisis Ekonomi Indonesia dan Langkah Reformasi", Pidato Ilmiah disampaikan dalam acara Dies Natalis Universitas Indonesia ke-48, Kampus UI Depok, 7 Februari 1998.

Kasim, Ifdhal dan Endang Suhendar, Tanah Sebagai Komoditas, Cet. Pertama, Jakarta: ELSAM, 1996.

Nisar, Said, H. M., Kajian tentang Pembaruan Agraria dan Pengelolaan SDA TAP MPR NO: IX/MPR/2001, paper lepas.

Rajaguguk, Erman dalam disertasinya yang bejudul, "Hukum Agraria, Pola Penguasaan Tanah dan Kebutuhan Hidup", Cet. Pertama, Jakarta: Chandra Pratama, 1995.

Sujadi, Suparjo.'Pembaharuan Hukum dalam Revisi UUPA, Kajian dari Peranan Hukum dalam Pembangunan Ekonomi”, Majalah Hukum dan Pembangunan, Edisi Khusus Dies-Natalis UI, February 2001.

\section{Internet}

"Apeksi Sumbagsel Tuntut Otonomi Pertanahan", <http://kompas.com/ ver1/nusantara/0611/14/15112.htm>, diakses, Selasa 19 Agustus 2006.

"DPRD Kota Bekasi Pertanyakan Kejelasan Status BPN", <http://www.kompas.com/metro/news/0308/19/102947.htm,>, diakses 19 Agustus 2006.

"Adeksi menolak Perpres No. 10 Tahun 2006, tentang Badan Pertanahan Nasional", <http://www.adeksi.or.id/detail/detailpressrelease.php? $\mathrm{id}=6>$, diakses 19 Desember 2006.

$<$ http://www.bangyos.com/id_berita-isi.php?cid=1\&id=274>, diakses Rabu, 26 Juli 2006. 
FSPI., "Pandangan dan Sikap FSPI tentang Program Pembaruan Agraria Nasional", dalam situs <http://www.fspi.or.id/index.php?option= com_content\&task $=v i e w \& i d=366 \&$ Itemid $=37>$, diakses 29 November $200 \overline{6}$.

Gorontalo (SIB)., "8,1 Juta Hektar Lahan Di Indonesia Akan Di Bebaskan Untuk Rakyat", <http://www.hariansib.com/content/view/14799/38/>, diakses 25 November 2006.

Medan Bisnis., "ProgramReformasi Agraria: Pemerintah Bagikan 8,2 Juta Hektar Lahan buat Petani", <http://www.fspi.or.id/index.php?option= com_content\&task=view\&id=357\&Itemid=62>, diakses 29 September $200 \overline{6}$.

PBHI., "Rencana Pemerintah menjalankan "Reforma Agraria" di Indonesia, ${ }^{\prime} \quad<$ http://www.pbhi.or.id/content.php?id=251\&id_tit=7>, diakses 19 Oktober 2006.

TEMPO Interaktif., "Pemerintah Bagikan 9 Juta Hektar Tanah" Kamis, 28 September 2006| 19:54 WIB <http://www.tempointeraktif.com/hg/ ekbis/2006/09/28/brk,20060928 84977,id.html>, diakses 29 September 2006.

Winoto, Joyo., Harian Kompas, 13 Desember 2006 dikutip dari situs Bappenas: $<$ http://perpustakaan.bappenas.go.id/pls/kliping/data_access. show_file_clp?v_filename=F9767/8.htm>, diakses 18 Desember 2006. 